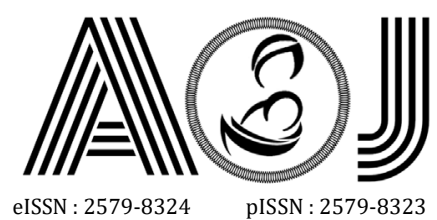

eISSN : 2579-8324
pISSN : 2579-8323

\title{
RESEARCH
}

\section{The Incidence of Overactive Bladder (OAB) in KIA Poly Patients at Pauh Health Center in Padang City Using Overactive Bladder Symptoms Score (OABSS)}

Bobby Indra Utama ${ }^{1}$, Widayat ${ }^{2}$, Berriandi Arwan ${ }^{2}$

Affiliations : 1. Sub Division of Urogynecology, Obstetrics and Gynecology Department, Faculty of Medicine, Andalas University, Dr. M. Djamil Central General Hospital Padang; 2. Resident of Obstetrics and Gynecology, Faculty of Medicine, Andalas University, Dr. M. Djamil Central General Hospital Padang

Correspondence: Bobby Indra Utama, email : bobby_utama@yahoo.com, Hp: 08116660500

\section{Abstract}

Objective : This study looked at the incidence of overactive bladder (OAB) in KIA poly patients at Pauh Health Center in Padang City using Overactive Bladder Symptomps Score (OABSS).

Method: This research is descriptive. The sampling technique was purposive sampling by considering inclusion and exclusion criteria. The inclusion criteria were women of ideal reproductive age (20-35 years) who had given birth spontaneously, were not pregnant, did not suffer from neurological disorders, diabetes, post bladder surgery and or urinary tract infections and were not treated with Overactive Bladder $(O A B)$, while the exclusion criteria are not willing to take part in the study. The study was carried out at the KIA Poly of Pauh City Health Center in Padang during January 2019. The variable in this study was Overactive Bladder $(O A B)$.

Result : In this study, 97.22\% of respondents experienced complaints of overactive bladder (OAB), (97.14\%) experienced an urgent complaint, and only a small percentage (2.86\%) of respondents experienced urinary incontinence. The results of this study indicate that respondents who did not experience complaints of overactive bladder $(O A B)$ were respondents with the smallest parity (parity 1).

Conclusion : Most respondents experienced complaints of overactive bladder (OAB) and urgency, and only a small proportion of respondents experienced urinary incontinence. The results of this study indicate that respondents who did not experience complaints of overactive bladder (OAB) were respondents with the smallest parity (parity 1).

Keywords: overactive bladder (OAB), Urgensi,inkontinensia urin, Overactive Bladder Symptom Scores $(O A B S S)$

\section{INTRODUCTION}

Overactive Bladder ( $O A B$ ) is a collection of complex symptoms consisting of urgency (a very strong desire to urinate suddenly and difficult to resist), with or without urinary incontinence, usually accompanied by a frequency (urinating up to more than 8 times a day) and nocturia (awakened to urinate more than 1 time). ${ }^{1,2,3}$

The Januari Continence Society (ICS) defines OAB as a symptom of urgency with or without symptoms of urgency incontinence (urge incontinence) which is usually followed by 


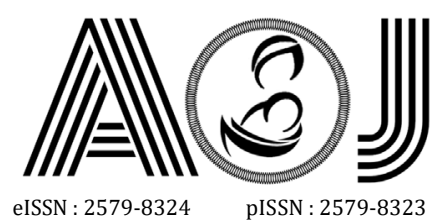

eISSN : 2579-8324
pISSN : 2579-8323

Ruang Redaksi Andalas Obstetrics and Gynecology Journal, Lantai 3 PPDS Obstetri dan Ginekologi Universitas Andalas, RSUP DR. M. Djamil Padang, Jl. Perintis Kemerdekaan Padang, Sumatera Barat 25127

Website:

http://jurnalobgin.fk.unand.ac.id/index.php/JOE

frequency and nocturia. Meanwhile, Paul Abrams (2002) defines OAB as a syndrome with several symptoms of Lower Urinary Tract Symptoms (LUTS) related to urine storage with urgency as the main parameter. The clinician defines $O A B$ as a clinical syndrome characterized by strong urge to urinate (urgency), insistence urinary incontinence (wet $O A B$ ) or without insistence urinary incontinence ( Dry $O A B$ ). The term $O A B$ is used if no evidence of infection or other pathological causes is found. ${ }^{4,5}$

Overactive bladder $(O A B)$ is a condition related to the disturbance of the voiding process. $O A B$ is characterized by a characteristic symptom of urination. $O A B$ is not a life threatening condition, so patients and health workers are often underestimated. However, the impact of $O A B$ is quite large on daily activities, quality of life, and a sense of well-being. $O A B$ is associated with a decrease in quality of life that is equivalentto other chronic diseases such as diabetes mellitus. ${ }^{6,7} \mathrm{OAB}$ is a long-term condition that has the potential to interfere with the quality of life of patients and has a significant economic impact in the long run. ${ }^{7}$

Various studies conducted in Europe and in America show that the prevalence of OAB on these two continents is almost the same, ie, approximately $17 \%$ of the general population suffers from OAB. Research conducted by National Overactive Bladder Evaluation (NOBLE) states that $37 \%$ of $O A B$ patients complain of insistence urinary incontinence, otherwise known as wet $O A B$ (wet) and $63 \%$ not accompanied by insistence urinary incontinence or dry $O A B$. The 'wet' $O A B$ prevalence will increase with age. 56 tis stated that 'dry' $O A B$ is more common in men than women ( $36 \%$ compared to $7 \%$ ) and conversely 'wet' $O A B$ is more common in women (9.3\% compared to $2.4 \%)$.

Symptoms of $O A B$ include presence of urgency, frequency, nocturia, can be accompanied by or without urge incontinence. To find out the severity of $O A B$, patients can fill out the $O A B$ scoring system designed by Blaivas. These symptoms cause a decrease in quality of life, including the limited physical, psychological, social, sexual, and work productivity activities. $^{2,8}$

Although $O A B$ is diagnosed only based on symptoms, its assessment is very important for patients and doctors, especially for evaluating the effectiveness of treatment. Multi-item questionnaires have been introduced to evaluate the impact of $O A B$ and treatment outcomes. For example, two different OAB symptom scores (OABSS) were developed by Homma et al and JG Blaivas et al and there were also OAB (AOB-q) and King's Health Questionnaire (KHQ) questionnaires that targeted quality of life. One of the main concerns for doctors who provided $O A B$ treatment was the lack of a widely accepted questionnaire for the assessment of OAB.

OABSS was published in the urology journal in 2007, a few months after the publication of OABSS Homma. Blaivas also uses the OABSS acronym, but this assessment is completely different. The authors mention that although there are many validated questionnaires for 


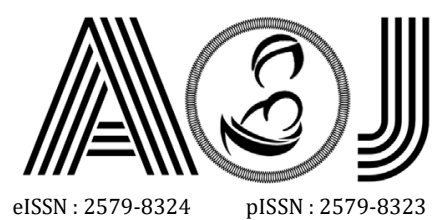

eISSN : 2579-8324
pISSN : 2579-8323
ANDALAS OBSTETRICS AND GYNECOLOGY JOURNAL

Alamat Korespondensi:

Ruang Redaksi Andalas Obstetrics and Gynecology Journal, Lantai 3 PPDS Obstetri dan Ginekologi Universitas Andalas, RSUP DR. M. Djamil Padang, Jl. Perintis Kemerdekaan Padang, Sumatera Barat 25127

Website:

http://jurnalobgin.fk.unand.ac.id/index.php/JOE

evaluating symptom of lower tract urinary, here there is no validated OABSS so that the measurement of all aspects of OAB includes the degree of response to urgency. Blaivas OABSS quantifies all aspects of $O A B$ and includes the degree of response to urgency. ${ }^{8,9}$

At present, first-line OAB therapy includes lifestyle changes, physical and / or behavioral therapy, regulating voiding schedules, and administration of antimuscarinic drugs. First-line therapy can provide a fairly good response, but is very patient compliance. In Januari, studies on second-line therapy in OAB still relatively small.

Non-pharmacological therapy is the first choice for $O A B$ patients. The best is a combination with pharmacological therapy. Surgery is only done if non-pharmacological therapy and pharmacological therapy fails. With this treatment, expected that the quality of life of patients with OAB can be increased. ${ }^{2,11,12,13}$

There are only a few data on the incidence of $O A B$, so the authors want to find out the incidence of OAB in KIA poly patients at Pauh Kota Padang Health Center from Januari 2019.

The purpose of this study was to determine the incidence of OAB sufferers in KIA poly patients at Pauh Health Center in Padang City by using OABSS (Overactive Bladder Symptomps Score).

\section{METHOD}

This research is descriptive. Data analysis is done univariately. Sampling techniques are purposive sampling by considering inclusion and exclusion criteria. The inclusion criteria in this study were women of ideal reproductive age (20-35 years) who had given birth spontaneously, were not pregnant, did not suffer from neurological disorders, diabetes, post bladder surgery and or urinary tract infections and were not treated with OAB. The exclusion criteria from this study were not willing to take part in the study. The study was carried out at the KIA Polyclinic in Pauh, Padang City during January 2019. Variable in this study was Overactive Bladder (OAB).

\section{RESULTS}

Based on research conducted at the KIA Polyclinic in Pauh City of South Sumatra in January 2019, 36 patients met the inclusion criteria. The distribution of samples based on the score of the Blaivas overactivebladder $(\mathrm{OAB})$ questionnaire can be seen in Table 1 below.

Table 1. Distribution of samples based on the score of the Blaivas overactivebladder (OAB) questionnaire

\begin{tabular}{ccc}
\hline OAB Score & $\mathrm{n}$ & $\%$ \\
\hline 0 (No OAB complaints) & 1 & 2,78 \\
$1-28$ (There is an OAB complaints) & 35 & 97,22 \\
Total & 36 & 100 \\
\hline
\end{tabular}




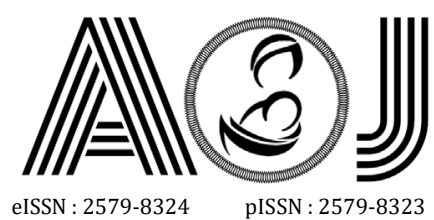

eISSN : 2579-8324
pISSN : 2579-8323

Ruang Redaksi Andalas Obstetrics and Gynecology Journal, Lantai 3 PPDS Obstetri dan Ginekologi Universitas Andalas, RSUP DR. M. Djamil Padang, Jl. Perintis Kemerdekaan Padang, Sumatera Barat 25127

Website:

http://jurnalobgin.fk.unand.ac.id/index.php/JOE

Table 1 above shows that most (97.22\%) of the sample experienced overactive bladder (OAB) complaints.

Table 2. Final Regression Model of Characteristic Association

\begin{tabular}{ccc}
\hline Type of Overactive Bladder & $\mathrm{n}$ & $\%$ \\
\hline Urgency & 35 & 97,22 \\
No Urgency & 1 & 2,78 \\
Total & 36 & 100 \\
\hline
\end{tabular}

The table above shows that the (97.14\%) of the sample experienced complaints of urgency (difficult to resist urination).

Table 3. Distribution of samples based on the level of urinary incontinence

\begin{tabular}{ccc}
\hline Level of urinary incontinence & $\mathrm{n}$ & $\%$ \\
\hline Perfectly controlled & 6 & 17,14 \\
Very good & 6 & 17,14 \\
Well & 14 & 40 \\
Bad & 8 & 22,86 \\
Not controlled at all & 1 & 2,86 \\
Total & 35 & 100 \\
\hline
\end{tabular}

The table above shows that only a small percentage $(2.86 \%)$ of respondents cannot control urine at all (incontinence).

Table 4. Distribution of OAB sufferers based on parity

\begin{tabular}{ccccc}
\hline & $\mathrm{P} 1$ & $\mathrm{P} 2$ & $\mathrm{P} 3$ & Total \\
\hline Suffering from OAB & $15(93,75)$ & $14(100)$ & $6(100)$ & $35(97,22)$ \\
Does not suffer from OAB & $1(6,25)$ & 0 & 0 & $1(2,78)$ \\
Total & 16 & 14 & 6 & $36(100)$ \\
\hline
\end{tabular}

The table above shows that only a small percentage (6.25\%) of patients with parity 1 did not experience of overactive bladder $(O A B)$, while patients with more than one parity, all experienced overactive bladder (OAB).

\section{DISCUSSION}

The results of this study show that most (97.22\%) of the sample experienced overactivebladder $(O A B)$ complaints. There are several studies conducted in women in general, namely in 5502 women in 11 countries in Asia (India, Pakistan, North Korea, Taiwan, Philippines, Malaysia, Indonesia, Thailand, Hong Kong, China and Singapore) it was found that the prevalence of OAB in women in Asia amounted to $53.1 \%{ }^{14}$

The National Overactive Bladder Evaluation (NOBLE) conducted a survey by telephone 


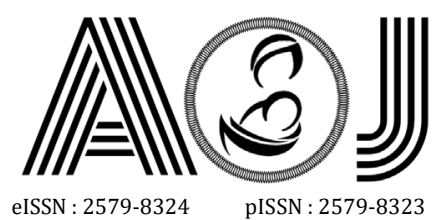

eISSN : 2579-8324
pISSN : 2579-8323

Ruang Redaksi Andalas Obstetrics and Gynecology Journal, Lantai 3 PPDS Obstetri dan Ginekologi Universitas Andalas, RSUP DR. M. Djamil Padang, Jl. Perintis Kemerdekaan Padang, Sumatera Barat 25127

Website:

http://jurnalobgin.fk.unand.ac.id/index.php/JOE

in the United States. The overall prevalence of OAB in women was $16.9 \%$ of 11,740 study samples. ${ }^{15}$

Some literature mentions risk factors that affect the occurrence of overactive bladder disorders $(\mathrm{OAB})$ are age, parity, mode of delivery, menopause, obesity, and a history of previous hysterectomy or gynecological surgery. Millard (2001) states that women who have a vaginal birth history have a 2.5 times greater risk of developing urinary disorders than women who have never experienced labor. ${ }^{11,16}$

According to Rubin (2003), women who have a Caesarean section will suffer less urinary incontinence than women who give birth normally. The birth process can affect the elasticity of the pelvic cavity where there is stretching in the muscles and tissues during childbirth.

As a result of this stretching can damage the pudendal nerve, pelvic nerve, muscle and surrounding pelvic tissue which can affect the stretching ability of the urethral spingter to contract in response to increased intra- abdominal pressure. ${ }^{11}$

The results of this study indicate that most $(97.14 \%)$ of the sample experienced complaints of overactivebladder (OAB) with urgency, where respondents had a very strong desire to urinate which was difficult to delay. This is in line with a survey conducted on nearly 17,000 people aged 40 years or more in 6 European countries with 16.5\% reported experiencing one or more of urgency, frequency incontinence or urgency incontinence. In the USA it was reported that $16.9 \%$ of women over the age of 18 experienced the above. ${ }^{17}$

The study also showed that the majority (40\%) of the sample had the ability to withstand urine discharge well, only (2.86\%) samples had urinary incontinence. A recent study in Europe of 18-year-old women or more 35\% reported unconscious urine output in the last 30 days, of which $20 \%$ reported symptoms of urgency incontinence, $37 \%$ stress urinary incontinence (SUI) and 33\% mixed incontinence. Symptoms of urgency and mixed incontinence increase with age. ${ }^{17}$ In general, the results of this study show a higher number compared to the results of previous studies because in this study the sampling was limited to the inclusion criteria, namely women of ideal reproductive age(20- 35 years) who had given birth spontaneously, were not pregnant, not suffering from neurological disorders, diabetes, post bladder surgery and or urinary tract infections and not in $O A B$ therapy.

Recent epidemiological studies have produced data on the incidence of $O A B$ and its effects on quality of life. A group of case control studies in 919 patients identifiedfrom a prevalence study in America showed the consequences of incontinence in a specific health condition related to quality of life ( $H R Q L=$ health quality of life) scale for OAB (OAB-q) . ${ }^{17}$

Problems caused by $O A B$ include disruption of physical activity and work, social interactions, psychological problems (depression), disturbances in sleep patterns, and sexual problems which are all disruptions to the quality of life. Overactive bladder (OAB) is a condition that can be treated and does not turn off. In general, OAB treatment is done 


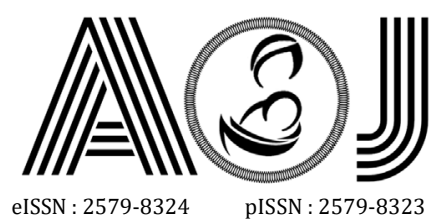

eISSN : 2579-8324

pISSN : 2579-8323

Ruang Redaksi Andalas Obstetrics and Gynecology Journal, Lantai 3 PPDS Obstetri dan Ginekologi Universitas Andalas, RSUP DR. M. Djamil Padang, Jl. Perintis Kemerdekaan Padang, Sumatera Barat 25127

Website:

http://jurnalobgin.fk.unand.ac.id/index.php/JOE

conservatively and operative action is only done if the conservative treatment fails. With this treatment, it is expected that the quality of life for patients with OAB can be increased. ${ }^{10,17}$

\section{CONCLUSION}

Based on the results of this study, it can be concluded that the majority of respondents experienced complaints of overactive bladder (OAB) and urgency, and only a small percentage of respondents experienced urinary incontinence. parity 1 ).

\section{REFERENCES}

1. Banakhar MA, Al-Shaiji TF, Hassouna MM. Pathophysiology of overactive bladder. Int Urogynecol j 23. 2012; 975- 982.

2. Purnomo BB. Dasar-dasar urologi. ed 3. Jakarta: Sagung seto, 2011;165-172.

3. Saputra KP. Overactive bladder. Dalam: pendidikan urologi berkelanjutan IV - Lower tract dysfunction. Malang: SMF Urologi RSU dr. Saiful Anwar. 2011: 72.

4. Rahardjo HE, Hariwibowo R. Pilihan terapi pada overactive bladder refrakter. eJKI. Vol 2. 2014.

5. Sumardi $\mathrm{R}$, et al. Test-retest reliability of the indonesian version of the overactive bladder symptom scores (OABSS) and its correlation with standard assessment tools. Acta Maedica Indonesiana 44(3).2012; 214-219.

6. Irwin DE, Milsom I, Hunskaar S, Reilly K, Kopp Z, Herschorn S, et al. Population- based servey of urinary incontinence, overactive bladder, and other lower urinary tract symptoms in five countries: result of the EPIC study. Eur Urol. 2006;50;1306-1315.

7. Athanasopoulos A, Guzma SA. Reevaluating the health-related quality of life impact and the economic burden of urgency urinary incontinence. Eur Urol Suppl. 2011; 10:37.

8. Lin YT, Chou ECL. Assessment of overactive bladder (OAB) - symptom

9. Blaivas JG, Panagopoulos G, Weiss JP, Somaroo C. Validation of the overactive bladder symptom scores. T dia Journal of Urology.178 ${ }^{\text {th }}$ Vol. 2007; 543-547.

10. Rahardjo HE, editor. Panduan tatalaksana inkontinensia urin pada dewasa. Perkumpulan Kontinensia Indonesia; 2012.

11. Permana RU. Prevalensi dan faktor-faktor resiko overactive bladder pada paramedis perempuan di RSUP H. Adam Malik Medan 2008; FK-USU: 1-26.

12. Hullfish KL, Fenner DE, Sorser SA, Visgor J, Clayton A, Steers WD. Postpartum depression, urge urinary incontinence, and overactive bladder syndrome: Is there an association ?. Int Urogynecol J. 2007; 1121- 1126.

13. Lai H, Gardner V, Vetter J, Andriole GL. Correlation between psychological stress levels and the severity of overactive bladder symptoms. BMC Urology. 2015: 1-7. 


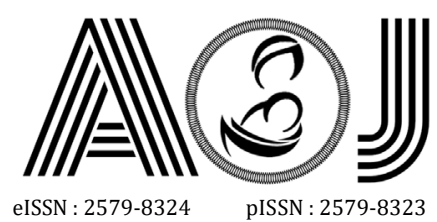

eISSN : 2579-832
pISSN : 2579-8323

Ruang Redaksi Andalas Obstetrics and Gynecology Journal, Lantai 3 PPDS Obstetri dan Ginekologi Universitas Andalas, RSUP DR. M. Djamil Padang, Jl. Perintis Kemerdekaan Padang, Sumatera Barat 25127

Website:

http://jurnalobgin.fk.unand.ac.id/index.php/JOE

14. Lapitan MC, Chyeon PLH. The Epidemiology of overactive bladder among females in asia : A Questionnaire survey. Int Urogynecology Journal.12 ${ }^{\text {th }}$ Vol. 2001: 226-231.

15. Cheng $\mathrm{CL}$, Li JR, Lin CH, Groat WC. Positive association of female overactive bladder symptoms and estrogen deprivation.Medicine Journal. 2016.

16. Zinner N, Harnett M, Sabounjian L, Sandage B, Dmochowski R, Staskins D. The overactive bladder symptomcomposite score : A Composite symptom score of toilet voids, urgency severity and urge urinary incontinence in patients with overactive bladder. The Journal of Urology. 173th Vol. 2006; 1639-1643.

17. Mullins CD, Subak LL. New perspectives on overactive bladder : Quality of life impact, medication persistency, and treatment cost. The american journal of managed care. 2005 